\title{
The Management of Congenital Ureteral Duplication Anomalies Complications - Case Presentation
}

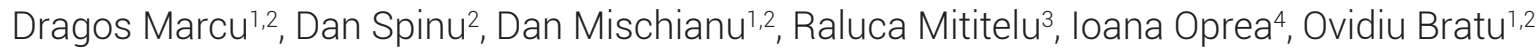

\begin{abstract}
Introduction: Ureteral anomalies often represent a great challenge for physicians regarding their diagnostic and the therapeutical management, ureteral duplication being one of the most frequent urogenital congenital malformations. Material and methods: We present the case of a patient with complete right pyelo- ureteral duplication, upper right hydronephrotic destroyed renal unit secondary to a large ureterocele, patient for whom we have practiced right partial heminephroureterectomy. Results: The postoperative evolution was favorable without any immediate complications. During the periodic postoperative follow-up intravenous urography was performed, investigation that revealed a normal right renal function. Conclusions: Imagistic investigations such as contrast CT examination, magnetic resonance urography and even intravenous urography have a major role in clarifying this pathology and helping guiding the therapeutical protocol.
\end{abstract}

Keywords: ureteral duplicity, ureterocel, management.

\section{Rezumat}

Introducere: Malformațiile aparatului urogenital reprezintă deseori o adevărată provocare pentru medici în ceea ce priveşte diagnosticul şi stabilirea conduitei terapeutice adecvate, duplicitatea pieloureterală fiind una dintre cele mai frecvente anomalii ale aparatului urinar. Material şi metodă: Vă prezentăm cazul unui pacient cu duplicitate pieloureterală dreaptă completă, cu unitatea renală superioară distrusă morfofuncțional, secundar unui ureterocel de mari dimensiuni, caz pentru care am practicat nefroureterectomie parțială şi rezecția endoscopică a ureterocelului. Rezultate: Evoluția postnefroureterectomie parțială a fost favorabilă, pacientul revenind la o lună de la data intervenției pentru rezecția ureterocelului drept. În cadrul evaluărilor ulterioare, urografia intravenoasă a arătat o funcție renală normală pe partea dreaptă. Concluzii: Investigații imagistice precum examinarea CT cu substanță de constrast, uro-RM sau urografia intravenoasă (deşi este considerată de către unii medici o investigație de domeniul trecutului) au rol semnificativ în lămurirea acestor patologii, precum şi în orientarea atitudinii terapeutice.

Cuvinte cheie: duplicitate pieloureterală, ureterocel, management.

\footnotetext{
${ }^{1}$ Clinic of Urology, „Dr. Carol Davila” Emergency University Central Military Hospital, Bucharest, Romania

${ }^{2}$ Clinical Departament 3, „Carol Davila" University of Medicine and Pharmacy, Bucharest, Romania

${ }^{3}$ Departament of Nuclear Medicine, „Dr. Carol Davila” Emergency

University Central Military Hospital, Bucharest, Romania

${ }^{4}$ Intensive Care Unit, „Dr. Carol Davila” Emergency University

Central Military Hospital, Bucharest, Romania
}

\section{Corresponding author.}

Dan Spinu, Clinical Departament 3, „Carol Davila"University of Medicine and Pharmacy, Bucharest, Romania. 


\section{INTRODUCTION}

Ureteral anomalies often represent a great challenge for physicians regarding their diagnostic and therapeutical management. Ureteral duplication is one of the most frequent urogenital congenital malformations, usually more frequent in female patients, with an incidence rate estimated at approximately $1 \% \%^{1,2}$.

Embryology is essential for understanding the development of the urinary system and its anomalies. The ureter development starts from the first month of the intrauterine life. Responsible for the urinary pathway formation is the Wolffian duct out of which the ureteral bud arises and ramifies forming the urinary collecting system ${ }^{3}$.

In what concerns the physiopathology of the ureteral duplication this implies the appearance of two ureteric buds from the Wolffian duct that invade the nephrogenic blastema, leading to two separate ureters and to kidney pelvic duplicity. Incomplete ureteral duplication appears when the urereteral bud divides in the proximity of the kidney base leading to two different ureters that arise from the kidney, ureters that along their pathway towards the bladder merge and form a single ureter. According to literature incomplete ureteral duplication, also known as ureter fissus is up to three times more frequent than complete ureteral $\mathrm{du}^{-}$ plication. The incomplete duplication of the ureter is usually in the proximal segment of the ureter (proximal ureter fissus) and extremely rare in the distal segment of the ureter ${ }^{3,4}$. According to the Meyer-Weigert rule, in patients with complete ureteral duplication, the ureter draining the upper renal unit has an ectopic bladder insertion towards the inferior and medial part of the bladder when compared with the opening of the ureter that drains the lower renal unit, orifice that it is located more laterally and superiorly. Usually the pyelo-ureteral duplication (especially the proximal incomplete ureteral duplication) is asymptomatic, being discovered during imagistic investigations for other pathologies, especially during contrast imaging techniques such as intravenous urography or contrast CT scans ${ }^{3,4}$.

Often complete ureteral duplication is associated with vesicoureteral reflux and as well as with other anomalies, the most frequent being the ureterocele. In numerous cases one of the ureteral orifices (usually the one that drains the upper renal unit) has an ectopic opening (outside the bladder trigone) in the urethra or in the vagina, leading to continuous urinary dribbling and urinary incontinence ${ }^{5-7}$. At the beginning of the $20^{\text {th }}$ century (1912), Leshnew described for the first time the ureterocele, pathology that consists in the cys- tic dilatation of the distal ureter, the intravesical and submucosal segment. According to its location the ureterocele can be orthotopic (completely located inside the bladder) or ectopic (a part of the ureterocele is located in the urethra or at the level of the bladder neck) . Regarding the pathogenesis of the ureterocele several studies have stated that persistence or incomplete dissolution of the Chwalla membrane has a major role in the appearance of this urinary tract anomaly ${ }^{3,8-10}$.

Numerous studies have reported that patients with complete ureteral duplication are more likely to present ureterocele, especially the ureter draining the upper renal unit. Usually the ureterocele is an asymptomatic pathology, but quite often due to urinary stasis it can be associated with ureterohydronephrosis, recurrent urinary tract infections, flank pain, urinary lithiasis, hematuria, pyuria and it can even lead to sepsis ${ }^{4,8,9}$.

\section{CASE PRESENTATION}

We present the case and the therapeutical management that we have adopted for a patient with complete pyeloureteral duplication, upper right hydronephrotic destroyed renal unit secondary to a large ureterocele.

A 31 years old male patient, without a significant medical history, presented in our clinic for right lumbar pain and intermittent macroscopic hematuria. The ultrasound examination revealed grade IV right hydronephorisis, corresponding to the upper half kidney, with important atrophy of the renal parenchyma and a normal lower half kidney, this suggesting a pyeloureteral duplicity. The bladder examination has shown the presence of a large cystic mass at the level of the bladder trigone which extended towards the bladder neck, therefore raising the suspicion of right ureterecele and explaining the upper right ureterohydronephrosis and renal atrophy. This diagnostic was confirmed by CT examination which revealed a complete right pyeloureteral duplicity, right ureterocele, grade IV ureterohydroneprosis corresponding to the upper renal unit with consecutive renal atrophy. The CT scans have also revealed an incomplete left pyeloureteral duplication.

Given the patients diagnostic and its symptoms we have decided that the correct therapeutical management should be right heminephroureterectomy, followed by endoscopic resection of the giant ureterocele. Prior to the laparotomy we have performed cystoscopy and we have tempted to catheterize the ureteral orifice corresponding to the ureter that drained the urine from the lower half renal unit, in order to insert a double $\mathrm{j}$ stent which would have made it easier to identify the normal ureter during the laparotomy, but we could not identify 

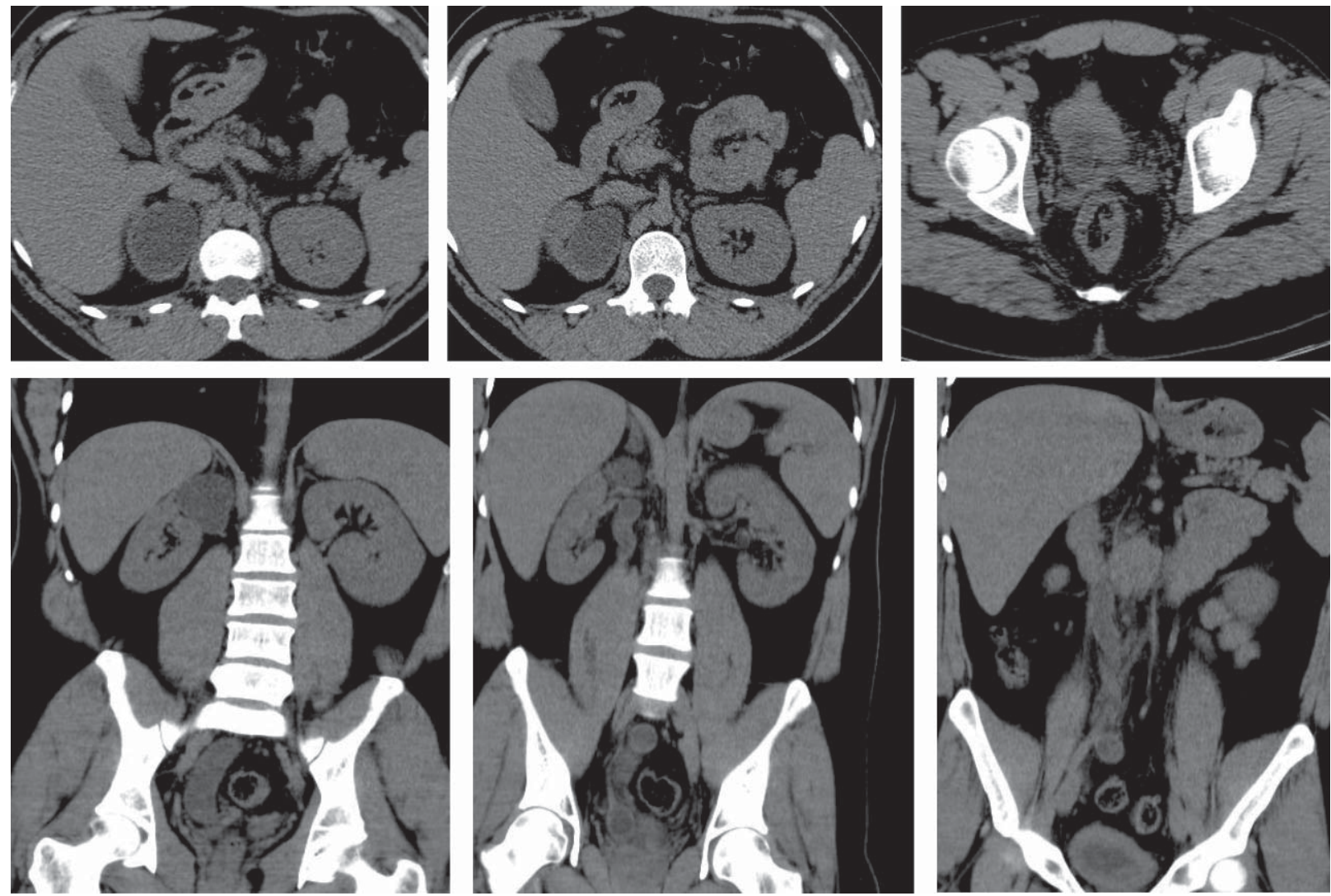

Figure 1-5. Preoperative CT scans.

the ureteral orifice due to the large dimensions of the ureterocele.

Under general anesthesia we have performed exploratory laparotomy. We have identified and isolated the two ureters, the dilated ureter which corresponded to the upper renal unit and the normal ureter. We have dissected the dilated ureter towards the bladder and near its implantation in the bladder we have ligated and sectioned it. During the dissection maneuvers it was noticed that the right kidney presented one renal artery and two renal veins, one for each renal unit. After isolating the artery and the two renal veins we have performed partial nephrectomy removing the upper destroyed renal unit and its ureter.

The postoperative evolution was favorable, without any major complications. One month after the surgery, we have performed the endoscopic resection of the right ureterocele. During the postoperative periodic
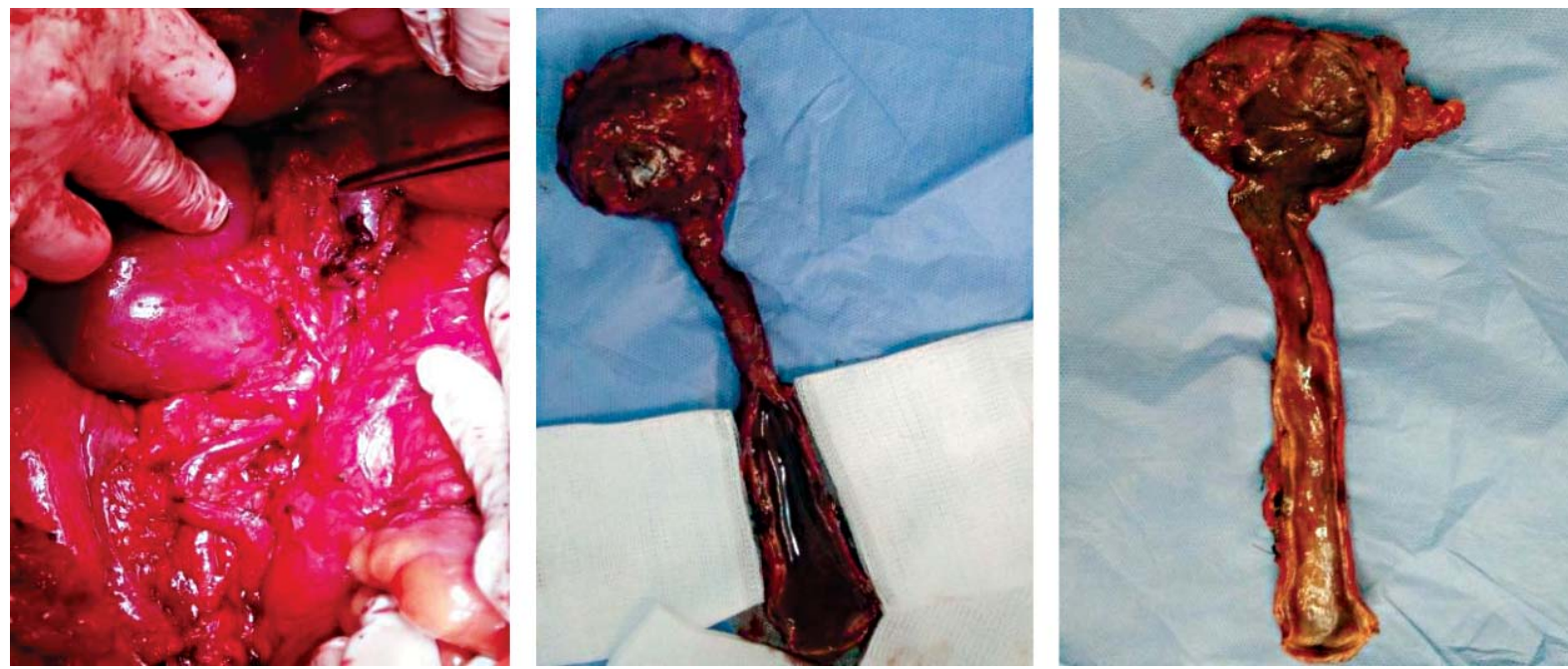

Figure 6-8. Intraoperative and postoperative pictures. 

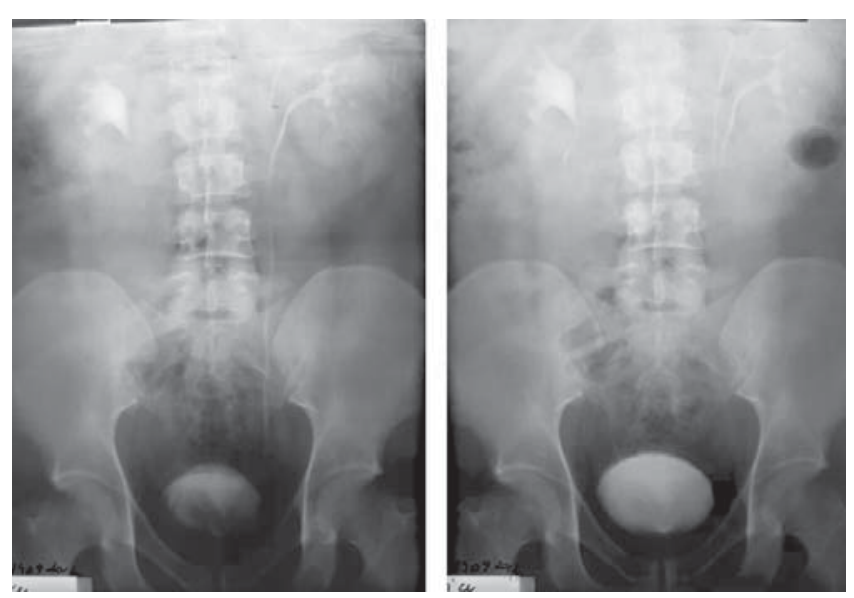

Figure 9, 10. Postoperative intravenous urography pictures.

evaluation we have performed intravenous urography which revealed a normal right renal function.

\section{DISCUSSIONS}

Duplication ureteral anomalies and their complications often create confusion in terms of diagnostic and therapeutical management. Imagistic investigations such as contrast CT examination, magnetic resonance urography and even intravenous urography (despite the fact that it is considered by some physicians an outdated imagistic investigation) have a major role in clarifying this pathology and helping guiding the therapeutical protocol. These anomalies are usually asymptomatic being discovered incidentally during investigations for an unrelated illness, but the patients can also present for recurrent urinary tract infections, flank pain, hematuria. Ultrasound examination is an efficient imagistic technique for establishing the diagnostic of ureterocele. Cystoscopy permits the direct evaluation of the ureterocele and bladder endoscopic exploration in order to identify the ureteral orifices ${ }^{4,11}$.

The therapeutical management depends on the type of ureteral duplication, associated complications and patient's symptoms. For patients with ureterocele and recurrent urinary tract infections endoscopic incision or resection of the ureterocele could be sufficient for eliminating the obstructive cause that frequently leads to urinary retention and recurrent infections, but several articles have reported high rates of secondary surgeries, especially for the ectopic ureterocele cases ${ }^{12-15}$.
According to literature the risk of further surgery fallowing ureterocele incision in patients with orthotopic ureterocele is estimated to range between $55 \%$ and $65 \%$, while for the patients with ectopic ureterocele the risk is even higher being estimated to be over $75 \% 8,16,17$. Often patients with complete ureteral duplication and ureterocele associate an obstructed upper renal unit, obstruction that will eventually lead to parenchymal atrophy and loss of the upper renal unit function, due to the increased pressure in the upper renal cavities, thus explaining the appearance of renal failure 9 .

For the cases where the endoscopic approach has failled open surgery or the laparoscopic approach with ureterocele resection and reimplantation of the ureters in the bladder is a viable solution, in order to avoid renal atrophy and renal failure. Heminephroureterectomy should be performed for the patients where these complications have already occurred ${ }^{18}$.

In a 2015 article regarding the transvesical laparoscopic approach in the management of ureteral duplicity with or without ureterocele the authors reported good outcomes in regards to the vesicoureteral reflux, ureterohydronephrosis and recurrent urinary tract infections ${ }^{9}$.

Urinary lithiasis (especially ureteral stones) is a frequent complication that can be encountered in patients with ureteral duplication malformations and associated ureterocele, with an incidence rate ranging between $15 \%$ and $40 \%$. Flexible ureteroscopy with in situ laser lithotripsy is a good solution for this type of patients, often this procedure providing excellent results ${ }^{19}$.

\section{CONCLUSIONS}

Ureteral anomalies often represent a great challenge for physicians regarding their diagnostic and therapeutical management, ureteral duplication being one of the most frequent urogenital malformations.

According to literature the ureterocele frequently associates with complete pyeloureteral duplicity. Therefore the incidental finding of an ureterocele during bladder ultrasound examination should be followed by other imagistic investigations that could reveal the presence of an unknown pyeloureteral duplicity.

In terms of therapeutic management this depends on the type of ureteral duplication, associated complications and patient's symptoms. 


\section{References}

1. Kawahara $\mathrm{T}$, Ito $\mathrm{H}$, Terao $\mathrm{H}$, et al. Ureteroscopy assisted retrograde nephrostomy (UARN) for an incomplete double ureter. Urol Res 2012;40:781-2. http://dx.doi.org/10.1007/s00240012-0486-y

2. Inamoto K, Tanaka S, Takemura K, et al. Duplication of the renal pelvis and ureter: Associated anomaliesand pathological conditions. Radiat Med 1983;1:55-64.

3. Dorko F, Tokarčík J, Výborná E. Congenital malformations of the ureter: anatomical studies. Anatomical Science International 2015. DOI 10.1007/s12565-015-0296-8.

4. Sen V, Aydogdu O, Yonguc T, Bozkurt IH, Polat S, Basmaci I. Endourological treatment of bilateral ureteral stones in bilateral ureteral duplication with right ureterocele. Can Urol Assoc J 2015;9(7-8):E511-3. http://dx.doi.org/10.5489/cuaj.2553

5. Smakal O. Diagnosis and treatment of birth defects in children doubled kidneys. Urolog Pract, Olomouc 2010, 11(6):316-318.

6. Fernbach SK, Feinstein KA, Spencer K, et al. Ureteral duplication and its complications. Radiographics 1997;17:109-27. http:// dx.doi.org/10.1148/radiographics.17.1.9017803

7. Spinu D, Bratu O, Madan V, Farcas C, Radulescu A, Popescu R, Mischianu D. Left renal cyst-left duplex kidney with compromised superior renal unit and ectopic ureteral orifice in the prostatic urethra - Journal of Medicine and Life, vol. 6, issue 2, aprjun, 2013, ISSN: 1844-122x

8. Sander JC, Bilgutay AN, Stanasel I, Koh CJ, Janzen N, Gonzales ET, Roth DR, Seth A. Outcomes of Endoscopic Incision for the Treatment of Ureterocele in Children at a Single Institution. J Urol. 2015 February; 193(2): 662-666. doi:10.1016/j. juro.2014.08.095.

9. Dada SA, Rafiu MO, Olanrewaju TO. Chronic renal failure in a patient with bilateral ureterocele. Saudi Med J 2015; Vol. 36 (7): 862-864. doi: 10.15537/smj.2015.7.11786
10. Vijay MK, Vijay P, Dutta A, Gupta A, Tiwari P, Kumar S, Bera MK, Das RK, Kundu1 AK. The Safety and Efficacy of Endoscopic Incision of Orthotopic Ureterocele in Adult. Saudi J Kidney Dis Transpl 2011; 22(6):1169-1174.

11. Fufezan O, Tătar S, Dee AM, Cramariuc R, Asăvoaie C, Coşarca $M$. Large spectrum of complete urinary collecting system duplication exemplified by cases. Pictorial essay. Med Ultrason 2013, Vol. 15, no. 4, 315-315 DOI: 10.11152/mu.2013.2066.154 of2

12. Blyth B, Passerini-Glazel G, Camuffo C, et al. Endoscopic incision of ureteroceles: intravesical versus ectopic. J Urol. 1993, 149:556

13. Hagg MJ, Mourachov PV, Snyder HM, et al. The modern endoscopic approach to ureterocele. J Urol. 2000; 163:940.

14. Cooper CS, Passerini-Glazel G, Hutcheson JC, et al. Long-term followup of endoscopic incision of ureteroceles: intravesical versus extravesical. J Urol. 2000; 164:1097.

15. Di Renzo D, Ellsworth PI, Caldamone AA, et al. Transurethral puncture for ureterocele-which factors dictate outcomes? J Urol, suppl. 2010; 184:1620.

16. Husmann D, Strand B, Ewalt D, et al. Management of ectopic ureterocele associated with renal duplication: a comparison of partial nephrectomy and endoscopic decompression. J Urol. 1999; 162:1406.

17. Merlini E, Lelli Chiesa P. Obstructive ureterocele-an ongoing challenge. World J Urol. 2004; 22:107.

18. Abouassaly R, Gill IS, Kaouk JH. Laparoscopic upper pole partial nephrectomy for duplicated renal collecting systems in adult patients. Urology 2007 (69), 1202-1205.

19. Gharbi Y, Gargah T, Boukesra T, Hellal Y, Sayed S. Ureterocele containing a stone in a duplex system. Saudi J Kidney Dis Transpl 2013; 24: 984-987. 